\title{
Ecotoxicity, Occurrence, and Removal of Pharmaceuticals and Illicit Drugs from Aquatic Systems
}

\author{
Harsh Mohan ${ }^{1 \mathbb{D}}$, Sejal Singh Rajput ${ }^{1 \mathbb{D}}$, Ekta B. Jadhav ${ }^{2 \mathbb{D}}$, Mahipal Singh Sankhla ${ }^{1}{ }^{\mathbb{D}}$, Swaroop S \\ Sonone $^{2(\mathbb{D})}$, Swapnali Jadhav ${ }^{2}$ (D) ${ }^{\text {Rajeev }}$ Kumar $^{1}{ }^{(\mathbb{D}}$ \\ 1 Department of Forensic Science, School of Basic and Applied Sciences, Galgotias University, Greater Noida; \\ harshmohan110@gmail.com (H.M.); rajputsejal001@gmail.com (S.S.R); mahipal4n6@gmail.com (M.S.S); \\ rajeev4n6@gmail.com (R.K.); \\ 2 Government Institute of Forensic Science, Aurangabad, Maharashtra; ekta.4n6@gmail.com (E.B.J); \\ sononeswap4@gmail.com (S.S.S); jadhavswapnali6760@gmail.com (S.J.); \\ * Correspondence: mahipal4n6@gmail.com;
}

Scopus Author ID 57219964786

Received: 17.12.2020; Revised: 16.01.2021; Accepted: 18.01.2021; Published: 30.01.2021

\begin{abstract}
Pollutants of legal pharmaceuticals and illicit drugs are causing many adverse effects on the environment. Pollutants are arising from waste products and from pharmaceuticals or illegal drugs that have not been disposed of properly. Pharmaceuticals and illegal drugs are becoming subject of concern for the past few decades after they attracted considerable attention because they do not willingly biodegrade \& remain toxic. Pharmaceuticals compounds such as antibiotics, anti-inflammatory, psychotropic, human drugs, hormones, and illicit drugs usually occur in wastewater from households, hospitals, health care clinics, veterinary, etc. ends in the water system. They potentially impact human health \& aquatic life. Recent studies confirm legal pharmaceuticals \& illegal drug residue in drinking water, surface water \& groundwater. Wastewater treatment plants (WWTPs) have been considered as hotspots of Pharmaceuticals residue. This removes contaminants from water using physical, chemical $\&$ biological processes. This review focuses on the occurrence, toxicity, and elimination of legal pharmaceuticals and illicit drugs in water systems.
\end{abstract}

Keywords: water contamination; illegal drugs; pharmaceuticals; toxicity; water system; aquatic.

(C) 2021 by the authors. This article is an open-access article distributed under the terms and conditions of the Creative Commons Attribution (CC BY) license (https://creativecommons.org/licenses/by/4.0/).

\section{Introduction}

Water is the most plentiful and essential compound for all known forms of life, including humankind. Thus, it is vital to supply water from small to big cities and towns. Since water is directly connected with human welfare and its quantity, the essential concern is water quality [1]. The globally increasing industrialization and urbanization caused damage and contaminated natural water ecosystems with their wastes. This may include different kinds of toxic pollutants such as domestic waste, industrial chemical waste, heavy metals, pesticides, fertilizers, and many more, which cause potentially serious implications on human and animal health [2-6]. The increasing medicinal needs and thus increased consumption of pharmaceuticals have triggered pharmaceutical industries for more production, which eventually caused the release of more pharmaceutical industry and hospital waste in aquatic ecosystems [7]. The high occurrence of pharmaceuticals and illicit drugs as pollutants in the aquatic system includes oral drugs, about $90 \%$ excreted from the human body and consequently ending up in the aquatic systems [8]. Lipid regulators, antibiotics, anticonvulsants, and nonsteroidal anti-inflammatory drugs (NSAIDs) have been considered four commonly found 
classes of pharmaceuticals in water systems [9]. Pharmaceuticals are released into water systems via majorly two means, such as their inappropriate removal into water treatment systems and schedule excretion after human administration. Although pharmaceuticals are used for the betterment of human health through treatment and prevention of various diseases as well as improvement of health conditions, the high use and consumption of these pharmaceuticals may contaminate water at such a level that it cannot be used for a specific purpose $[10,11]$. Along with legal medicinal drugs, the manufacture of illegal drugs and abused controlled substances has also been pushed due to their high use and consumption.

Consequently, their residues' release via illegal disposal and human excreta has become a potential source of drug pollution in water systems [12,13]. Several studies have been conducted over the wastewater treatment processes of a wide range of pharmaceuticals, illegal drug metabolites, and their chemical pathways. They also stated the unchanged residues even after passing through the wastewater treatment plants (WWTPs) [14-17]. These globally arising contaminants present water quality issues of concern with hazardous effects on water ecosystems and human health. The growth of antibiotic-resistant bacteria is also a potential adverse effect of drug pollution in water systems [18]. The different conventional water treatment methods used for adsorption on activated carbons and advanced oxidation processes that utilize ozone, gamma radiation, electro-oxidation, and ultraviolet radiation in Wastewater treatment plant have been employed to eliminated a wide range of drug contaminants in water systems [19].

\section{Occurrence of LIDs in Water Systems}

Pharmaceuticals and illicit drugs are the major examples of pollutants that are frequently found in aquatic systems [20-21]. The pharmaceuticals like medicinal drugs, human drugs, veterinary drugs, hormones, anticonvulsants, anti-inflammatories, antidepressants, antibiotics, psychotropic, and illegal drugs like cocaine, opioids, ecstasy-group substances, cannabis, amphetamine-type substances (ATSs), and steroids are globally manufactured by various pharmaceutical and illegal drug manufacturing industries. Due to these drugs' inappropriate disposal, their residues are frequently found on surface water, drinking water, and wastewater in unchanged form or as active metabolites [22-25]. Although the presence and detection of illegal drugs in water systems is poorly understood, some studies have shown the partial metabolism and excretion via urine and feces of these illicit drugs as parent compounds or as metabolites [26, 27].

\subsection{Surface and groundwater.}

Since the high consumption and demand of LIDs consequently increased their manufacture and thus disposal in the environment, particularly water ecosystems, their residues and metabolites are significantly detected in the rivers, lakes, and groundwater [28]. These contaminants found in water due to poor elimination during WWTPs and direct discharge of manufacturing drug residues such as antibiotics, antacids, steroids, lipid-lowering drugs, tranquilizers, antidepressants, analgesics, anti-inflammatory, antipyretics, beta-blockers, and stimulants undergoes different processes after released into water system [19, 29-30]. These drugs interact with sediments, groundwater, soil, and surface water, with different chemical processes like degradation, leaching, sorption, and transport in surface runoff. Some of the 
emerging illicit drugs are not willingly sorbed to inorganic matter or sub-soils but may enter the surface or groundwater systems due to their polar nature [31].

\subsection{Drinking water.}

Pharmaceuticals are continuously released in the water systems, including drinking water, which is prevalent at even trace amounts due to their direct administration. This can potentially harm drinking water quality by introducing into drinking water supplies and ecosystems and, consequently, affecting human health [19]. Various LIDs such as antibiotics, antidepressants, veterinary drugs, anti-inflammatories, psychotropics, human drugs, hormones, anticonvulsants, and steroids occur widely in drinking water and wastewater $[32,33]$. These chemicals introduced in drinking water can cause a threat to every consuming individual from infants, babies to the adult, and oldsters. This may pose serious health effects such as cancer, liver, or kidney failure $[34,35]$.

\subsection{Sewage effluents/wastewater.}

Pharmaceuticals from households, veterinary, hospitals, and health care clinics and accidentally or deliberately disposed of illegal drugs eventually end up in raw wastewater and then in wastewater treatment plants. After the metabolism of administered drugs in the human body, they are excreted in the original form and/or as metabolites via human feces and urine. This excreta is discharged straight into sewage effluents. Thus, wastewater effluent discharges can be one of the major pathways of pharmaceuticals, and illegal drug contaminants in water ecosystems as the surface overflow or leaching of human waste via these sewage effluents into freshwater environments cannot be neglected [36-39]. The body metabolizes lIDs, some drugs may be partially metabolized, and some may be completely degraded; these types of excreted drugs and/or their metabolites are directly introduced into the sewage system and eventually transported from wastewater treatment plants (WWTPs) to water systems [40-42]. The 6monoacetyl morphine (6-ACM), morphine (MOR), 2-ethylidene-1,5-dimethyl-3,3diphenylpyrrolidine (EDDP), codeine (COD), tramadol (TRA) and methadone (MET) are the most frequent illicit drug contaminants [43-52].

\subsection{Protected areas of the aquatic environment.}

The high consumption of LIDs and the improper wastewater treatments pushed these compounds even to the aquatic environment's protected areas such as estuaries, natural wetlands, lagoons, and deltas. Due to the occurrence of a wide range of endemic flora and fauna, these areas have ecological and economic importance [53]. Several studies revealed the absence of 3, 4-methylenedioxyamphetamine (MDA), heroin, THC, and methamphetamine while cocaine and its metabolites' significant presence 3,4-methylenedioxyNmethamphetamine (MDMA) and methadone in these areas. The expose of pharmaceuticals to the protected areas of aquatic environments has been understood more clearly than illicit drugs. Some studies showed that pharmaceuticals such as carbamazepine, propranolol, and ibuprofen occurred in these areas. Even some research includes notably contaminated areas such as Doñana Park in Spain and Yangtze Estuary in China [54-57]. 


\section{Eminent Sources of LIDs in Water}

The pharmaceutical industry's quick growth, well-known accessibility of diverse types of therapeutically, and enlarged pharmaceuticals consumption increased the amount of contaminants in the municipal wastewater [58]. Domestic sewage, industrial waste, municipal waste, and metabolites of pharmaceuticals enter the wastewater stream due to improper disposal of the water-systems and custom excretion after human intakes directly discharged into the natural aquatic system are the major cause of contamination. Untreated waste discharge leads to water contamination. The major source of contamination of surface and groundwater water is the discharge of manufacturing effluents without treatment inside the water bodies [59-63]. Inappropriate disposal of dangerous health-care waste is a topic of concern. The peoples that are to blame for this misapprehension are pharmacists, doctors, drug abusers, nurses, and other health-care professionals. It also spaces an improperly substantial financial and human possessions load on health care authorities to manage the problem. Healthcare waste inflows the usual domestic waste stream and ultimately ends up being disposed of in municipal landfill sites. After health-care waste is discharged into landfills, pollution of groundwater possibly will arise [64]. The exposer of illegal drugs into the drinking water, surface water, and groundwater is a further problem. There are no standard tests on the occurrence of pharmaceuticals in drinking water, surface water, and groundwater. This difficulty is frequently increasing due to the increased intake of pharmaceuticals via society [65].

\subsection{Pharmaceutical industry waste.}

Pharmaceuticals industries are the main contributor to water contamination in surface water and groundwater, including aquatic environments [64]; the high growth of pharmaceutical industries increased by the high utilization of pharmaceuticals, which cause the high detection of these pollutants in the aqueous environment. The High utilization of pharmaceuticals via humans provides a diverse pathway from which pharmaceuticals be able to go in water environments. Pharmaceutical compounds are usually hydrophilic and biologically activated; thus, the human body can easily acquire them [66-67]. The human body has entirely absorbed some pharmaceuticals; a small number of pharmaceuticals are excreted from the human body. These pharmaceuticals go into the "sewage system" and ultimately enter into the environment all through by sewage discharge or by leakage of wastewater from "sewage treatment plants" which dump into the water systems

[68-69]. Pharmaceuticals such as analgesics, antibiotics, anti-inflammatory, blood lipid regulators, antiepileptic, hormones and beta-blockers, are detected in aquatic environments in the concentration range from "nanograms to micrograms per liter"[70-71]. The wide-ranging studies have been approved on pharmaceutical contaminants in the environment. Pharmaceuticals get accumulate in the environment in a medical, household, or industrial wastes. Pharmaceuticals are the foundation of long-term hazards due to their accumulation [72-73].

\subsection{Hospital waste.}

Large quantities of pharmaceutical residues are detected in wastewater, beginning from health care centers and hospitals [74]. Wastewater from hospitals contains more and higher concentrations of drugs and pharmaceuticals than household and industrial effluent. Pharmaceuticals drugs from health-center \& hospital are more toxic and higher biological 
active. The majority of hospital drains are connected to the main sewers directly even though assured waste is disposed of separately via STP on-site and special waste contractor [75]. The production and discarding of waste pharmaceuticals is an issue to strict control in the cases of retailers, wholesalers, manufacturers, and hospitals, even though there are some remote cases of hospitals disposing of waste \& expired pharmaceuticals by the drains [76-77]. Drugs for treating cancer are toxic by nature to proliferate cells, and genotoxicity detects in hospital waste is also credited to such drugs [78]; common drugs such as diclofenac, sulfamethoxazole, iopromide, and 17-alpha-ethinylestradiol, etc., are discharged from hospital [79]. Hospital wastewater is frequently unspecified designated the most toxic to aqueous life. There are definitely quite a few studies wherein the genotoxic activity of hospital wastewater is confirmed [80].

\subsection{Illegal drug manufacture industry waste.}

Misusing of drugs is now a worldwide dilemma with a major straight or roundabout unpleasant impact on social welfare and human health [81]. "Illicit drugs" are those drugs that are used for "nonmedical purpose" \& forbidden by international or national laws. Illicit drugs are categories as cocaine, cannabis, opioids, ecstasy-group substances, and amphetamine-type substances [82]. Loads of illicit drugs are constantly unconfined into the aqueous environment due to their partial removal in wastewater treatment plants (WWTP). These substances are incompletely metabolized in the human body and accomplish the wastewater network as a compound mixture of parental compounds and metabolites, where they are able to be detected from ng $\mathrm{L}-1$ to $\mu \mathrm{g} \mathrm{L}-1$ [76]. Prohibited drugs and their metabolites are regularly discharged into wastewaters due to usual "human excretion" after banned and authorized use or irregular direct dumping of undercover drug-producing laboratory wastes into sewage systems. After human consumption of illicit drugs, their metabolites are excreted through feces, urine, sweat, and saliva. The emission procedure occurs again and again even when illegal drugs are administered by diverse methods such as swallowing, injecting, smoking, and snorting. The number of consumed drugs excreted unchanged and as their metabolites in feces and urine are able to be summarized as benzoylecgonine, cocaine, amphetamine, ecgonine methyl ester (3249methamphetamine MDMA, THC [83-85].

\section{Ecotoxicity of Pharmaceuticals in Water Systems}

In the latest studies about residues of pharmaceuticals in drinking and surface waters are greater than before in scientific publications[86]. Drug residues that are found in the aqueous environment are frequently as a mixture of compounds, not as single contaminants [87]; mostly, some small streams getting a quite large amount of the water from sewage water treatment plants are found to be significantly contaminated [88] pharmaceutical compounds that are present in the environment are high enough in concentrations to cause some major harm and considered as noxious [89]. The possible effects on the aquatic environment and human healthiness are "chronic more than acutely toxic and depend on exposure, that is susceptibility, bioavailability, to the compound in the query, and the degradability of the compound" [90]. The pharmaceutical named diclofenac is mainly complicated contaminates to eliminate from wastewater. "Diclofenac is discharged along with treated wastewater to surface water was it able to undergo accumulation in sediments". Diclofenac's "biodegradation can last up to several months" [91]. The occurrence of pharmaceuticals residue in water poses much 
pressure to human health $\&$ organisms living in the aquatic system since they show acute \& chronic toxicity to the aquatic system and human health.

\subsection{Adverse effects on aquatic ecosystems.}

The high consumption of pharmaceuticals pushes the rapid development of pharmaceutical industries [92]. The huge expenditure of pharmaceuticals by humans provides unusual ways to enter the water system [83]; chronic release and relatively low degradation make them pseudo-persistent in aquatic environments. "The aquatic ecosystem" consists of various groups of organisms such as invertebrates, plants, microorganisms, fish, or amphibians. Pharmaceuticals can directly or indirectly affect these organisms; the direct effect includes physiological changes within an organism [93]. Some general examples are Acute toxicity of Naproxen depending on a living organism for Oncorhynchus mykiss is $690 \mathrm{mg} / \mathrm{dm}^{3}$, and for cyanobacteria this is $12.3 \mathrm{mg} / \mathrm{dm}^{3}$; also, naproxen causes chronic toxicity to the phytoplankton. diclofenac poses much pressure to aquatic organisms counting fish since this pharmaceutical shows acute toxicity among non-steroidal anti-inflammatory drugs (NSAIDs). The EC50 "median effective concentration" of diclofenac for fish $14.5 \mathrm{mg} / \mathrm{dm} 3$ for phytoplankton; this is $22.43 \mathrm{mg} / \mathrm{dm} 3$. Diclofenac shows chronic toxicity to benthos and phytoplankton. Continuing exposure of diclofenac to Oncorhynchus mykiss cause damages to gills and kidneys. diclofenac and carbamazepine are possibly toxic to aquatic microbes. [94-98].

\subsection{Adverse effects on human health.}

There is growing concerned about the presence of emerging pharmaceuticals, then, current a novel worldwide water quality challenge with possible "serious implication to human health" [99]. The potential risk of introducing human health is a topic of concern, particularly for those countries that employ surface water for drinking purposes [100]. The trouble cause of "pharmaceuticals in drinking water can have a major crush on human health due to chronic exposure. If the human drinks about 2 liters per day and the amount of a "pharmaceutical in drinking water are $5 \mathrm{ng} / \mathrm{dm}^{3 "}$ - this means a person's daily consumption of this pharmaceutical is almost $10 \mathrm{ng}$. This small amount of dose Is ends up with $3650 \mathrm{ng} / \mathrm{year}$. If this rate is multiplied by humans' standard life expectancy ( 70 years), it would be $255,500 \mathrm{ng}$ ". This uninformed intake is able to show an adverse effect on human health. More concentration should be given to estrogens' occurrence in a water system can cause an increase in breast[gynecomastia] testicular cancer and decrease fertility in men [101-103]. Pharmaceuticals in the drinking water system are very dangerous to the elderly, babies, and even on infants and people who suffer from liver or kidney malfunction. "The occurrence of anticancer drugs in drinking water is dangerous for pregnant women due to fluorouracil it can go through the blood-placenta barrier, and consequently cause an embryotoxic and teratogenic effect" [104-105].

\subsection{Ecotoxicity of illegal drugs in water systems.}

Illicit drugs are constantly discharged into the water system due to their huge production and consumption [106]. The occurrence of "illegal drugs and their metabolites" needs consideration via an eco-toxicological viewpoint since studies found potential harmful results on the aquatic system. [107]. "Most illegal drugs, opiates, cocaine amphetamines these compounds possibly a major limitation is determining their effectiveness and potential 
toxicity" [108]. The studies on the ecological toxicity of illegal drugs in "scientific journalism" are limited and not methodical. Only a few pieces of information exist on the ecotoxicity of amphetamine, morphine, and cocaine on marine organisms. The toxicity of amphetaminesulfate to recently isolated Daphnia and Oncorhynchus mykiss and was studied. The outcome exposed comparatively more toxic between the 50 mentioned chemicals used via Multicentre Evaluation of in-vitro Cytotoxicity [109]. "The behavioral screening of cocaine sensitivity in Danio renio showed defect resultant from a mutation in different genes that influence dopaminergic signaling in the brain and retina" [110]. "The study on cyto-genotoxic consequence of cocaine on Dreissena polymorpha showed major primary DNA damage, raise in micronucleated cells and marked rise in apoptosis"[111] adverse effect of morphine on Elliptio complanata is the reduction of phagocytic and intracellular esterase activity, cell adherence and lipid peroxidation [112]. "The pharmacokinetics of morphine into Pseudopleuronectes americanus and seawater acclimated Oncorhynchus mykiss was reported by measuring the change in plasma morphine concentration for $100 \mathrm{~h}$ " [113]. Thus, it is normal to suppose from the existing information that the stimulatory or inhibitory effects of illegal drugs depend on the compound and the test organism.

\subsection{Adverse effects on aquatic ecosystems.}

Illegal drugs and "their metabolites" are acknowledged as pollutants of rising worry, "illegal drugs" are incompletely metabolized and excreted unaffected in feces and urine or as active metabolites reaching WWTPs. moreover, most wastewater treatment plants are deficient in the cure of effluents containing the banned drug, potentially dumped into aquatic systems. "Once in the water or sediment, these substances may interact and affect non-target organisms, and some evidence implies that illegal drugs may show pseudo-persistence since they give continuous environmental input, resultant in long-term exposure to aquatic organisms" [114]. Present studies show 4 main drug groups that cause global concern: cannabinoids, synthetic drugs (ecstasy and amphetamines), cocaine, and opioids [115-116]. Besides, illegal drugs as well as act together with the residue of another compound, "leading to unanticipated pharmacological interactions that may cause toxic effects on aquatic organisms" [117-118]. The study of cyto-genotoxic shows that the consequences of cocaine on Driessen polymorpha are DNA damage, enlarging of micronucleated cells, and a marked rise in apoptosis [119]. The behavioral show of cocaine sensitivity in Danio renio confirm defects consequential from a mutation in different genes that influence dopaminergic signaling in the brain and retina [120].

\subsection{Adverse effects on human health.}

Misuse of drugs is large-scale trouble with a major straight or roundabout adverse effect on human healthiness [121]. illicit drugs are a biological concern due to their possible longterm unfavorable effects on human's health [122]. "Illicit drugs are those drugs used for nonmedical medical purpose and banned by the government agencies". even though the concentration of different prohibited drugs and their metabolites on surface waters are "found in few $\mathrm{nm} / \mathrm{l}$ ". Their probable effects on human health cannot be ignored, particularly for "vulnerable populations" [123]. Illicit drugs pose a possible risk to human health when people drink polluted water for their whole life [124]. Therefore, some studies show illicit drugs in the water system cannot be that harmful because of their low concentration. However, it can be adverse if they expose for a long time period. 


\section{Removable of Pharmaceuticals from the Water System}

The majority of the wastewater treatment method does not let the entire elimination of micro contaminants of pharmaceuticals. The elimination of pharmaceuticals depends on the chemical and physical properties of the compound. Pharmaceuticals are eliminated through biodegradation. adsorption on activated sludge, flocculation, coagulation, adsorption, "photolysis on activated carbon, ozonation combined with $\mathrm{H}_{2} \mathrm{O}_{2}$ ". These methods let the elimination of pharmaceuticals from wastewater at a diverse rate $[125,126]$. On the other hand, most of them are not functional in municipal WTPs Beta-blockers cannot eliminate entirely. Atenolol is able to eliminate almost $30 \%$ through biotransformation. An irrelevant quantity of this "pharmaceutical is adsorbed on activated sludge". Metoprolol is eliminated at a low rate throughout biotransformation, about $10 \%$, the concentration of propranolol does not change during wastewater treatment [127-129].the Application of Ozonation in wastewater treatment increases the elimination of atenolol by about $86 \%$, and metoprolol has a success rate of $93 \%$ [130]. A non-steroidal anti-inflammatory is able to adsorb on activated sludge, most likely $80 \%$. still, the regular rate of adsorption ranges is considered between 21 to $40 \%$ [131]. biodegradation Diclofenac has a low elimination rate of not more than $25 \%$ due to the amount of $\mathrm{N}-\mathrm{H}$ atoms $\mathrm{Cl}$ and group that slow down the development of bacteria in wastewater. The photolysis method is effective in eliminating diclofenac via 25 to $75 \%[132,133]$. The function of membrane filters allows the taking away of diclofenac is about 58\%. Ozonation is able to let obtaining the elimination capability of more than $98 \%$. Combined ozonation with $\mathrm{H} 2 \mathrm{O} 2$ allows enough elimination of diclofenac $[134,135]$. The amount of diclofenac in treated wastewater is about $140 \mathrm{~g} / \mathrm{dm}^{3}$ to $1480 \mathrm{~g} / \mathrm{dm}^{3}$ [136]. Naproxen is eliminated about $50-80 \%$ from wastewater because of adsorption on activated sludge [137]. Adsorption on activated carbons let the taking away of naproxen about 52\%, with ozonation; this is about 90to $99 \%$. The combined ozonation with $\mathrm{H} 2 \mathrm{O} 2$ can eliminate more than $89 \%$ [129]. Photolysis can eliminate entire Naproxen (99 to 100\%) [138]. The application of membrane bioreactors can eliminate Naproxen from wastewater by more than $86 \%$ [128]. Ibuprofen is a very efficiently removed pharmaceuticals. The elimination rate of ibuprofen from wastewater is about 60$100 \%$. Sedimentation can eliminate ibuprofen from 12 to $45 \%$. The main method behind this procedure is a breakdown of hydroxyl and carbonyl groups, and the products of breakdown are eliminated through membrane filtration. [124]. Adsorption on activated carbons and ozonation can eliminate ibuprofen at a success rate of 99\%[122]. "Photocatalysis is also considering as capable elimination of ibuprofen. At the $\mathrm{TiO}_{2}$ concentration of $1.0 \mathrm{~g} / \mathrm{dm} 3$ and 30-minute introduction to light ibuprofen underwent approximately total disintegration" [139]. The paracetamol, acetylsalicylic acid, ketoprofen can be eliminated via sedimentation, coagulation, and flocculation, about 15 to $98 \%$. elimination of ketoprofen can be done by adsorption on activated sludge, which allows the elimination of up to 65 to $77 \%$ [122, 124]. However, membrane filtration is the most efficient technique for eliminating ketoprofen that caneliminate up to $98 \%$ [140]. "Paracetamol is adsorbed on activated sludge between $99 \%$ to $100 \%$ on membrane filters. It also competently eliminates (up to 90\%) through chlorination, adsorption on activated carbons, and ozonation. Paracetamol is considered to be one of the most efficiently eliminate pharmaceuticals in the process of wastewater treatment'[128]. Biodegradation of Acetylsalicylic acid can eliminate at the success rate of 80 to $98 \%$ [124].Carbamazepine is not easily eliminated with the processes of wastewater treatment. According to the studies, only 6 to $10 \%$ carbamazepine is able to eliminate. "Carbamazepine is vulnerable to biodegradation. It 
is considered as hard to remove due to the fact of no biodegradation of carbamazepine at the concentration of $0.5 \mathrm{mg} / \mathrm{dm}^{3}$ in saltwater is observed" [129]. Photolysis combines adsorption on activated sludge with allows the elimination of carbamazepine about $29 \%$. The most effective elimination of carbamazepine includes ozonation, which has a success rate of $90 \%$. The adsorption on activated carbons can eliminate up to $90 \%$, and when ozonation is combined with $\mathrm{H}_{2} \mathrm{O}_{2}$, the rate of success will become 98 to $99 \%$. Individually photolysis is less effective for eliminating "carbamazepine from wastewater". In contrast, membrane filters have shown a low elimination rate of about $13 \%$. According to the studies, biodegradation of diazepam up to $70 \%$ takes 84 days. Also, "adsorption of diazepam on activated sludge is insignificant (less than $2 \%$ )". Whereas adsorption on activated carbons eliminate about $99 \%$ and ozonation about $81 \%$ and considered as most effective methods for elimination of diazepam adsorption is able to eliminate Fluoxetine from wastewater about $92 \%$, and ozonation about $91 \%$ and when ozonation combined with $\mathrm{H}_{2} \mathrm{O}_{2}$ the rate of elimination rises up to $91 \%$ [139].

\section{Removable of Illicit Drugs from the Water System}

Since many illicit drugs discharge into the aquatic system, this is important to realize the elimination effectiveness of usual "wastewater treatment processes for chemicals of concern". The treated wastewater treatment plants effluents usually hold a lesser concentration of illicit drugs than the individual influents even though they are at unstable concentration depending on detection and location technique. "Hence, such influent and sewage analysis provide qualitatively or at best semi-quantitative information about the performance of wastewater treatment plants configurations to eliminate these illicit drugs"[131]. The treatment process used to treat polluted water differs significantly worldwide, with different component processes configured and operate differently depending on the climate, expertise, site-specific factors, and "water authority preference and relative cost". The elimination effectiveness of Wastewater treatment plants for various compounds with illegal drugs differs significantly depending on the treatment processes operating and the technology used. It is also probable that any microbial-mediated drug removal will be strongly influenced by the operational parameters, development and design, and environmental factors such as dissolved oxygen concentration and water temperature [132]. Different wastewater treatment plants might use diverse minor treatment method configurations, such as trickling filters, membrane bioreactors, or activated sludge treatment. Current studies confirmed that activated sludge treatment is further capable of eliminating illegal drugs than the "trickling filters", perhaps since "activated sludge processes" is more capable of elimination of chemical contaminants than trickling filters, with a considerable amount advanced "active microbial biomass substance and higher rate of oxygen input from mechanical aeration that would also improve volatilization" [133]. Solid waste is constantly eliminating in the form of waste activated sludge, so this may put an illegal drug into "elimination performance by adsorption to the solid phase". If we compare trickling filters with activated sludge treatment for elimination of diverse illegal drugs and found that activated sludge eliminates about 39\% METH, 99\% AMPH and 91\% cocaine even as elimination effectiveness of trickling filters for cocaine 37\%, METH 25\% and AMPH 89\%, was and in that order. The elimination effectiveness of trickling filter treatment and activated sludge process in the elimination of selected illegal drugs. [134] the inferior treatment by operating with low SRT and biological filters are lesser capable if we compare them to "activated sludge in eliminate illegal drugs and their metabolites, reporting high elimination (less than 90\%) for MDMA through activated sludge and for cocaine and its metabolite and 
49-80\%. Hence, SRT is one more important parameter that should be measured while assessing the elimination rate of wastewater treatment plants" [140]. The reported elimination for activated sludge is $100 \%$ for both METH and AMPH, $79 \%$ for cocaine, $90 \%$ for BE $98 \%$ for THC-COOH. , reported the lowest for cocaine (72\%) and the highest elimination rate for BE $(93 \%)$ in an Irish wastewater treatment plant using activated sludge treatment, while [136] standard elimination for $95 \% \mathrm{BE}$ and $95 \%$ cocaine. Ultrafiltration membranes use in the variation of activated sludge, the membrane bioreactor which is submerged into the activated sludge, is measured further efficient on illegal drug elimination than the regularly activated sludge, probably because "some mixture of higher operating biomass concentrations, longer SRT and enhanced sewage solids separation" [141] but new research is required for the recognition of elimination pathway, to let us differentiate among accurate drug degradation by "biodegradation or biotransformation [142].

\section{Conclusion}

Pharmaceutical and illegal drugs have become a concern over the last few decades. They have gained considerable attention as they do not voluntarily biodegrade and remain toxic. Due to high consumption of pharmaceutical and illicit drug, their industries are rapidly growingResidues of pharmaceuticals or illegal drugs, and their metabolites enter the wastewater stream due to discharge of manufacturing effluents without treatment and excretion after human consumption; they are discharged directly into the natural water system leading to pollution and affects human health and the environment. It is a big issue to efficiently eliminate pharmaceuticals and illegal drugs, besides another main concern pollutant, from wastewaters before their ejection. Adsorption, biodegradation on flocculation, activated sludge, adsorption on activated carbon, photolysis, and coagulation are methods by which pharmaceuticals can be removed. Suppose the pharmaceutical and illicit drugs waste continues to enter our environment in this manner, then one day. In that case, all the water bodies will get polluted and will bring many diseases. To avoid this, there is a need to regulate its use and disposal properly.

\section{Funding}

This review received no external funding.

\section{Acknowledgments}

This review has no acknowledgment.

\section{Conflicts of Interest}

The authors declare no conflict of interest.

\section{References}

1. Mishra, S.; Reddy-Noone, K.; Jain, A.; Verma, K.K. Monitoring organophosphorus pesticides and their degradation products formed by Fenton's reagent using solid-phase extraction-gas chromatography-mass spectrometry. International journal of environment and pollution 2006, 27, 49-63, https://doi.org/10.1504/IJEP.2006.010453.

2. Sankhla, M.S.; Kumar, R.; Prasad, L. Zinc Impurity in Drinking Water and Its Toxic Effect on Human Health. Indian Internet Journal of Forensic Medicine \& Toxicology 2019, 17, 84-87, http://dx.doi.org/10.5958/0974-4487.2019.00015.4 . 
3. Gulia, S.; Rohilla, R.; Sankhla, M.S.; Kumar, R.; Sonone, S. Impact of Pesticide Toxicity in Aquatic Environment. Biointerface Research in Applied Chemistry 2020, 11, 10131-10140, http://dx.doi.org/10.33263/BRIAC113.1013110140 .

4. Sankhla, M.S.; Kumar, R.; Agrawal, P. Arsenic in Water Contamination \& Toxic Effect on Human Health: Current Scenario of India. Journal of Forensic Sciences \& Criminal Investigation 2018, 10, 1-5, http://dx.doi.org/10.19080/JFSCI.2018.10.555781.

5. Sankhla, M.S.; Kumari, M.; Sharma, K.; Kushwah, R.S.; Kumar, R. Water contamination through pesticide $\&$ their toxic effect on human health. International Journal for Research in Applied Science \& Engineering Technology (IJRASET) 2018, 6, 967-970, http://dx.doi.org/10.22214/ijraset.2018.1146.

6. Sankhla, M.S.; Kumari, M.; Nandan, M.; Kumar, R.; Agrawal, P. Heavy metals contamination in water and their hazardous effect on human health-a review. Int. J. Curr. Microbiol. App. Sci 2016, 5, 759-766, http://dx.doi.org/10.20546/ijcmas.2016.510.082.

7. Bayer, A.; Asner, R.; Schüssler, W.; Kopf, W.; Weiß, K.; Sengl, M.; Letzel, M. Behavior of sartans (antihypertensive drugs) in wastewater treatment plants, their occurrence and risk for the aquatic environment. Environmental Science and Pollution Research 2014, 21, 10830-10839, https://doi.org/10.1007/s11356-014-3060-z.

8. Pothitou, P.; Voutsa, D. Endocrine disrupting compounds in municipal and industrial wastewater treatment plants in Northern Greece. Chemosphere 2008, 73, 1716-1723, https://doi.org/10.1016/j.chemosphere.2008.09.037.

9. Tijani, J.O.; Fatoba, O.O.; Babajide, O.O.; Petrik, L.F. Pharmaceuticals, endocrine disruptors, personal care products, nanomaterials and perfluorinated pollutants: a review. Environmental chemistry letters 2016, 14, 27-49, http://doi.org/10.1007/s10311-015-0537-z.

10. Owa, F.D. Water pollution: sources, effects, control and management. Mediterranean journal of social sciences 2013, 4, http://dx.doi.org/10.5901/mjss.2013.v4n8p65.

11. Buser, H.R.; Poiger, T.; Müller, M.D. Occurrence and environmental behavior of the chiral pharmaceutical drug ibuprofen in surface waters and in wastewater. Environmental science \& technology 1999, 33, 25292535, https://doi.org/10.1021/es981014w.

12. Szymonik, A.; Lach, J.; Malińska, K. Fate and removal of pharmaceuticals and illegal drugs present in drinking water and wastewater. Ecological Chemistry and Engineering $S$ 2017, 24, 65-85, https://doi.org/10.1515/eces-2017-0006.

13. Daughton, C.G. Illicit drugs in municipal sewage: Proposed new nonintrusive tool to heighten public awareness of societal use of illicit-abused drugs and their potential for ecological consequences, Pharmaceuticals and Care Products in the Environment 2001, 348-364, http://dx.doi.org/10.1021/bk-20010791.ch020.

14. Li, Z.; Undeman, E.; Papa, E.; McLachlan, M.S. High-throughput evaluation of organic contaminant removal efficiency in a wastewater treatment plant using direct injection UHPLC-Orbitrap-MS/MS. Environmental Science: Processes \& Impacts 2018, 20, 561-571, https://doi.org/10.1039/C7EM00552K.

15. Subedi, B.; Kannan, K. Occurrence and fate of select psychoactive pharmaceuticals and antihypertensives in two wastewater treatment plants in New York State, USA. Science of the Total Environment 2015, 514, 273-280, https://doi.org/10.1016/j.scitotenv.2015.01.098.

16. Borova, V.L.; Maragou, N.C.; Gago-Ferrero, P.; Pistos, C.; Thomaidis, N.S. Highly sensitive determination of 68 psychoactive pharmaceuticals, illicit drugs, and related human metabolites in wastewater by liquid chromatography-tandem mass spectrometry. Analytical and bioanalytical chemistry 2014, 406, 4273-4285, https://doi.org/10.1007/s00216-014-7819-3.

17. Evgenidou, E.N.; Konstantinou, I.K.; Lambropoulou, D.A. Occurrence and removal of transformation products of PPCPs and illicit drugs in wastewaters: a review. Science of the Total Environment 2015, 505, 905-926, https://doi.org/10.1016/j.scitotenv.2014.10.021.

18. Berendonk, T.U.; Manaia, C.M.; Merlin, C.; Fatta-Kassinos, D.; Cytryn, E.; Walsh, F.; Bürgmann, H.; Sørum, H.; Norström, M.; Pons, M.-N.; Kreuzinger, N.; Huovinen, P.; Stefani, S.; Schwartz, T.; Kisand, V.; Baquero, F.; Martinez, J.L. Tackling antibiotic resistance: the environmental framework. Nature Reviews Microbiology 2015, 13, 310-317, https://doi.org/10.1038/nrmicro3439.

19. Rivera-Utrilla, J.; Sánchez-Polo, M.; Ferro-García, M.Á.; Prados-Joya, G.; Ocampo-Pérez, R. Pharmaceuticals as emerging contaminants and their removal from water. A review. Chemosphere 2013, 93, 1268-1287, https://doi.org/10.1016/j.chemosphere.2013.07.059.

20. Pothitou, P.; Voutsa, D. Endocrine disrupting compounds in municipal and industrial wastewater treatment plants in Northern Greece. Chemosphere 2008, 73, 1716-1723, https://doi.org/10.1016/j.chemosphere.2008.09.037.

21. González-Mariño, I.; Quintana, J.B.; Rodríguez, I.; Cela, R. Determination of drugs of abuse in water by solid-phase extraction, derivatisation and gas chromatography-ion trap-tandem mass spectrometry. Journal of Chromatography A 2010, 1217, 1748-1760, https://doi.org/10.1016/j.chroma.2010.01.046.

22. Magesh, N.; Annam Renita, A.; Senthil Kumar, P. Practice on treating pharmaceutical compounds (antibiotics) present in wastewater using biosorption techniques with different biowaste compounds. A review. Environmental Progress \& Sustainable Energy 2020, 39, https://doi.org/10.1002/ep.13429. 
23. Liang, Y.; Liu, J.; Zhong, Q.; Yu, D.; Yao, J.; Huang, T.; Zhu, M.; Zhou, T. A fully automatic cross used solid-phase extraction online coupled with ultra-high performance liquid chromatography-tandem mass spectrometry system for the trace analysis of multi-class pharmaceuticals in water samples. Journal of Pharmaceutical and Biomedical Analysis 2019, 174, 330-339, https://doi.org/10.1016/j.jpba.2019.06.004.

24. Cizmas, L.; Sharma, V.K.; Gray, C.M.; McDonald, T.J. Pharmaceuticals and personal care products in waters: occurrence, toxicity, and risk. Environmental Chemistry Letters 2015, 13, 381-394, https://doi.org/10.1007/s10311-015-0524-4.

25. Hall, W.; Degenhardt, L.; Sindicich, N. Illicit Drug Use and the Burden of Disease. In: International Encyclopedia of Public Health. Heggenhougen, H.K., Ed. Academic Press: Oxford, 2008; pp. 523-530, https://doi.org/10.1016/B978-012373960-5.00355-5.

26. Zuccato, E.; Castiglioni, S. Illicit drugs in the environment. Philosophical Transactions of the Royal Society A: Mathematical, Physical and Engineering Sciences 2009, 367, 3965-3978, https://doi.org/10.1098/rsta.2009.0107.

27. Castiglioni, S.; Zuccato, E.; Chiabrando, C.; Fanelli, R.; Bagnati, R. Detecting illicit drugs and metabolites in wastewater using high performance liquid chromatography-tandem mass spectrometry. Spectroscopy Europe 2007, 19, 7-9.

28. Houeto, P.; Carton, A.; Guerbet, M.; Mauclaire, A.-C.; Gatignol, C.; Lechat, P.; Masset, D. Assessment of the health risks related to the presence of drug residues in water for human consumption: Application to carbamazepine. Regulatory Toxicology and Pharmacology 2012, 62, 41-48, https://doi.org/10.1016/j.yrtph.2011.11.012.

29. Moreno-González, R.; Rodriguez-Mozaz, S.; Gros, M.; Barceló, D.; León, V.M. Seasonal distribution of pharmaceuticals in marine water and sediment from a mediterranean coastal lagoon (SE Spain). Environmental Research 2015, 138, 326-344, https://doi.org/10.1016/j.envres.2015.02.016.

30. Al-Rifai, J.H.; Gabelish, C.L.; Schäfer, A.I. Occurrence of pharmaceutically active and non-steroidal estrogenic compounds in three different wastewater recycling schemes in Australia. Chemosphere 2007, 69, 803-815, https://doi.org/10.1016/j.chemosphere.2007.04.069.

31. Jones-Lepp, T.L.; Alvarez, D.A.; Petty, J.D.; Huckins, J.N. Polar Organic Chemical Integrative Sampling and Liquid Chromatography-Electrospray/Ion-Trap Mass Spectrometry for Assessing Selected Prescription and Illicit Drugs in Treated Sewage Effluents. Archives of Environmental Contamination and Toxicology 2004, 47, 427-439, https://doi.org/10.1007/s00244-004-3146-6.

32. Zhang, Y.; Geißen, S.-U.; Gal, C. Carbamazepine and diclofenac: Removal in wastewater treatment plants and occurrence in water bodies. Chemosphere 2008, 73, 1151-1161, https://doi.org/10.1016/j.chemosphere.2008.07.086.

33. Femina Carolin, C.; Senthil Kumar, P.; Janet Joshiba, G.; Vinoth Kumar, V. Analysis and removal of pharmaceutical residues from wastewater using membrane bioreactors: a review. Environmental Chemistry Letters 2020, 1-15, https://doi.org/10.1007/s10311-020-01068-9.

34. Aschengrau, A.; Weinberg, J.M.; Janulewicz, P.A.; Romano, M.E.; Gallagher, L.G.; Winter, M.R.; Martin, B.R.; Vieira, V.M.; Webster, T.F.; White, R.F.; Ozonoff, D.M. Affinity for risky behaviors following prenatal and early childhood exposure to tetrachloroethylene (PCE)-contaminated drinking water: a retrospective cohort study. Environmental Health 2011, 10, https://doi.org/10.1186/1476-069X-10-102.

35. Zwiener, C. Occurrence and analysis of pharmaceuticals and their transformation products in drinking water treatment. Analytical and Bioanalytical Chemistry 2007, 387, 1159-1162, https://doi.org/10.1007/s00216006-0818-2.

36. Castiglioni, S.; Zuccato, E.; Chiabrando, C.; Fanelli, R.; Bagnati, R. Detecting illicit drugs and metabolites in wastewater using high performance liquid chromatographytandem mass spectrometry. Spectroscopy Europe 2007, 19, 7-10.

37. Zorita, S.; Mårtensson, L.; Mathiasson, L. Occurrence and removal of pharmaceuticals in a municipal sewage treatment system in the south of Sweden. Science of The Total Environment 2009, 407, 2760-2770, https://doi.org/10.1016/j.scitotenv.2008.12.030.

38. Rodriguez-Mozaz, S.; Chamorro, S.; Marti, E.; Huerta, B.; Gros, M.; Sànchez-Melsió, A.; Balcázar, J.L. Occurrence of antibiotics and antibiotic resistance genes in hospital and urban wastewaters and their impact on the receiving river. Water research 2015, 69, 234-242, https://doi.org/10.1016/j.watres.2014.11.021 .

39. Sonone, S. S.; Jadhav, S.; Sankhla, M. S.; Kumar, R. Water Contamination by Heavy Metals and their Toxic Effect on Aquaculture and Human Health through Food Chain. Letters in Applied NanoBioScience 2020, 10, 2148-2166. https://dx.doi.org/10.33263/LIANBS102.21482166.

40. Clara, M.; Kreuzinger, N.; Strenn, B.; Gans, O.; Kroiss, H. The solids retention time-a suitable design parameter to evaluate the capacity of wastewater treatment plants to remove micropollutants. Water Research 2005, 39, 97-106, https://doi.org/10.1016/j.watres.2004.08.036.

41. Madikizela, L.M.; Tavengwa, N.T.; Chimuka, L. Status of pharmaceuticals in African water bodies: occurrence, removal and analytical methods. Journal of environmental management 2017, 193, 211-220, https://doi.org/10.1016/j.jenvman.2017.02.022 . 
42. Castiglioni, S.; Bagnati, R.; Melis, M.; Panawennage, D.; Chiarelli, P.; Fanelli, R.; Zuccato, E. Identification of cocaine and its metabolites in urban wastewater and comparison with the human excretion profile in urine. Water research, 2011, 45(16), 5141-5150. https://doi.org/10.1016/j.watres.2011.07.017.

43. Zuccato, E.; Castiglioni, S.; Bagnati, R.; Chiabrando, C.; Grassi, P.; Fanelli, R. Illicit drugs, a novel group of environmental contaminants. Water Research 2008, 42, 961-968, https://doi.org/10.1016/j.watres.2007.09.010.

44. Lin, A.Y.-C.; Lin, Y.-C.; Lee, W.-N. Prevalence and sunlight photolysis of controlled and chemotherapeutic drugs in aqueous environments. Environmental Pollution 2014, 187, 170-181, https://doi.org/10.1016/j.envpol.2014.01.005.

45. Terzic, S.; Senta, I.; Ahel, M. Illicit drugs in wastewater of the city of Zagreb (Croatia) - Estimation of drug abuse in a transition country. Environmental Pollution 2010, 158, 2686-2693, https://doi.org/10.1016/j.envpol.2010.04.020.

46. Baker, D.R.; Kasprzyk-Hordern, B. Spatial and temporal occurrence of pharmaceuticals and illicit drugs in the aqueous environment and during wastewater treatment: New developments. Science of The Total Environment 2013, 454-455, 442-456, https://doi.org/10.1016/j.scitotenv.2013.03.043.

47. Li, K.; Du, P.; Xu, Z.; Gao, T.; Li, X. Occurrence of illicit drugs in surface waters in China. Environmental Pollution 2016, 213, 395-402, https://doi.org/10.1016/j.envpol.2016.02.036.

48. Boleda, M.R.; Galceran, M.T.; Ventura, F. Monitoring of opiates, cannabinoids and their metabolites in wastewater, surface water and finished water in Catalonia, Spain. Water Research 2009, 43, 1126-1136, https://doi.org/10.1016/j.watres.2008.11.056.

49. Wang, D.-G.; Zheng, Q.-D.; Wang, X.-P.; Du, J.; Tian, C.-G.; Wang, Z.; Ge, L.-K. Illicit drugs and their metabolites in 36 rivers that drain into the Bohai Sea and north Yellow Sea, north China. Environmental Science and Pollution Research 2016, 23, 16495-16503, https://doi.org/10.1007/s11356-016-6824-9.

50. Mahjoub, O.; Dahchour, A.; Siebe, C. Emerging Pollutants in Irrigation Water: Origins. Fate, Risks, and Mitigation 2015, 43, 1267-1256.

51. Ebele, A.J.; Oluseyi, T.; Drage, D.S.; Harrad, S.; Abou-Elwafa Abdallah, M. Occurrence, seasonal variation and human exposure to pharmaceuticals and personal care products in surface water, groundwater and drinking water in Lagos State, Nigeria. Emerging Contaminants 2020, 6, 124-132, https://doi.org/10.1016/j.emcon.2020.02.004.

52. Kasprzyk-Hordern, B.; Dinsdale, R.M.; Guwy, A.J. The removal of pharmaceuticals, personal care products, endocrine disruptors and illicit drugs during wastewater treatment and its impact on the quality of receiving waters. Water Research 2009, 43, 363-380, https://doi.org/10.1016/j.watres.2008.10.047.

53. Vazquez-Roig, P.; Andreu, V.; Blasco, C.; Picó, Y. Risk assessment on the presence of pharmaceuticals in sediments, soils and waters of the Pego-Oliva Marshlands (Valencia, eastern Spain). Science of The Total Environment 2012, 440, 24-32, https://doi.org/10.1016/j.scitotenv.2012.08.036.

54. Thomas, K.V.; Bijlsma, L.; Castiglioni, S.; Covaci, A.; Emke, E.; Grabic, R.; Hernández, F.; Karolak, S.; Kasprzyk-Hordern, B.; Lindberg, R.H.; Lopez de Alda, M.; Meierjohann, A.; Ort, C.; Pico, Y.; Quintana, J.B.; Reid, M.; Rieckermann, J.; Terzic, S.; van Nuijs, A.L.N.; de Voogt, P. Comparing illicit drug use in 19 European cities through sewage analysis. Science of The Total Environment 2012, 432, 432-439, https://doi.org/10.1016/j.scitotenv.2012.06.069.

55. Postigo, C.; López de Alda, M.J.; Barceló, D. Drugs of abuse and their metabolites in the Ebro River basin: Occurrence in sewage and surface water, sewage treatment plants removal efficiency, and collective drug usage estimation. Environment International 2010, 36, 75-84, https://doi.org/10.1016/j.envint.2009.10.004.

56. Zuccato, E.; Castiglioni, S.; Bagnati, R.; Chiabrando, C.; Grassi, P.; Fanelli, R. Illicit drugs, a novel group of environmental contaminants. Water Research 2008, 42, 961-968, https://doi.org/10.1016/j.watres.2007.09.010.

57. Sankhla, M.S.; Kumar, R.; Prasad, L. Distribution and Contamination Assessment of Potentially Harmful Element Chromium in Water. Available at SSRN 3492307, 2019, 2, 1-6.

58. Afzal, M.S.; Ashraf, A.; Nabeel, M. Characterization of industrial effluents and groundwater of Hattar industrial estate, Haripur. Advances in Agriculture and Environmental Science: Open Access (AAEOA) 2018, 1, 70-77, https://doi.org/10.30881/aaeoa.00013.

59. Nosiphiwe, P.N.; Petros, M. Occurrence of pharmaceuticals in aquatic environments: A review and potential impacts in South Africa. South African Journal of Science 2020, 116, 1-7, http://dx.doi.org/10.17159/sajs.2020/5730.

60. Szymonik, A.; Lach, J. Hazard to the aquatic environment from the presence of pharmaceuticals. Environmental Engineering and Protection 2012, 15.

61. Halling-Sørensen, B.; Nors Nielsen, S.; Lanzky, P.F.; Ingerslev, F.; Holten Lützhøft, H.C.; Jørgensen, S.E. Occurrence, fate and effects of pharmaceutical substances in the environment- A review. Chemosphere 1998, 36, 357-393, https://doi.org/10.1016/S0045-6535(97)00354-8.

62. Clara, M.; Kreuzinger, N.; Strenn, B.; Gans, O.; Kroiss, H. The solids retention time-a suitable design parameter to evaluate the capacity of wastewater treatment plants to remove micropollutants. Water Research 2005, 39, 97-106, https://doi.org/10.1016/j.watres.2004.08.036. 
63. Madikizela, L.M.; Tavengwa, N.T.; Chimuka, L. Status of pharmaceuticals in African water bodies: Occurrence, removal and analytical methods. Journal of Environmental Management 2017, 193, 211-220, https://doi.org/10.1016/j.jenvman.2017.02.022.

64. Ayman, Z.; Işı, M. Pharmaceutically active compounds in water, Aksaray, Turkey. CLEAN-Soil, Air, Water 2015, 43, 1381-1388.

65. Gulia, S.; Sankhla, M.S.; Kumar, R.; Sonone S.S. Phytomicrobiome Studies for Combating the Abiotic Stress, Biointerface Research in Applied Chemistry 2020, 11, 10493-10509, https://dx.doi.org/10.33263/BRIAC113.1049310509

66. Golet, E.M.; Alder, A.C.; Hartmann, A.; Ternes, T.A.; Giger, W. Trace Determination of Fluoroquinolone Antibacterial Agents in Urban Wastewater by Solid-Phase Extraction and Liquid Chromatography with Fluorescence Detection. Analytical Chemistry 2001, 73, 3632-3638, https://doi.org/10.1021/ac0015265.

67. Sharma, V.K.; Anquandah, G.A.K.; Nesnas, N. Kinetics of the oxidation of endocrine disruptor nonylphenol by ferrate(VI). Environmental Chemistry Letters 2009, 7, 115-119, https://doi.org/10.1007/s10311-0080143-4. •

68. Michael, I.; Rizzo, L.; McArdell, C.S.; Manaia, C.M.; Merlin, C.; Schwartz, T.; Dagot, C.; Fatta-Kassinos, D. Urban wastewater treatment plants as hotspots for the release of antibiotics in the environment: A review. Water Research 2013, 47, 957-995, https://doi.org/10.1016/j.watres.2012.11.027.

69. Gahlinger, P.M. Illegal drugs: A complete guide to their history, chemistry, use and abuse. Penguin, 2004.

70. Kümmerer, K. Drugs in the environment: emission of drugs, diagnostic aids and disinfectants into wastewater by hospitals in relation to other sources - a review. Chemosphere 2001, 45, 957-969, https://doi.org/10.1016/S0045-6535(01)00144-8.

71. Party, E.A.H.W. Assessment of potential risks to the environment posed by medicinal products for human use (excluding products containing live genetically modified organisms). 1994.

72. Richardson, M.L.; Bowron, J.M. The fate of pharmaceutical chemicals in the aquatic environment. Journal of Pharmacy and Pharmacology 1985, 37, 1-12.

73. Giuliani, F.; Koller, T.; Würgler, F.E.; Widmer, R.M. Detection of genotoxic activity in native hospital waste water by the umuC test. Mutation Research/Genetic Toxicology 1996, 368, 49-57, https://doi.org/10.1016/S0165-1218(96)90039-7.

74. Loos, G.; Scheers, T.; Van Eyck, K.; Van Schepdael, A.; Adams, E.; Van der Bruggen, B.; Dewil, R. Electrochemical oxidation of key pharmaceuticals using a boron doped diamond electrode. Separation and Purification Technology 2018, 195, 184-191. https://doi.org/10.1016/j.seppur.2017.12.009.

75. Gartiser, S.; Brinker, L.; Uhl, A.; Willmund, M.; Krümmerer, K.; Daschner, F. Investigation of hospital effluents-the example of the Freiburg university hospital. Industrieabwässer 1994, 9, 1618-1624.

76. Vandam, L.; Matias, J.; McKetin, R.; Meacham, M.; Griffiths, P. Illicit Drug Trends Globally. In: International Encyclopedia of Public Health. 2016; pp. 146-156, http://doi.org/10.1016/B978-0-12-8036785.00223-X.

77. UNODC (United Nations Office on Drugs and Crime). World drug report. United Nations Publication; 2007. https://www.unodc.org/unodc/en/about-unodc/annual-report.html, Accessed on February 15, 2012.

78. Berset, J.D.; Brenneisen, R.; Mathieu, C. Analysis of llicit and illicit drugs in waste, surface and lake water samples using large volume direct injection high performance liquid chromatography-electrospray tandem mass spectrometry (HPLC-MS/MS). Chemosphere 2010, 81, 859-866, https://doi.org/10.1016/j.chemosphere.2010.08.011.

79. Boles, T.H.; Wells, M.J. Analysis of amphetamine and methamphetamine as emerging pollutants in wastewater and wastewater-impacted streams. Journal of Chromatography A 2010, 1217, 2561-2568, https://doi.org/10.1016/j.chroma.2010.01.014.

80. Verster, J.C. Editorial [Monitoring Drugs of Abuse in Wastewater and Air]. Current drug abuse reviews 2010, 3, 1-2, https://doi.org/10.2174/1874473711003010001.

81. Robinson Research Institute (RRI) The Robinson Research Institute. Endocrinology. Volume 7, 2008; pp. $15-24$.

82. Ternes, T.A. Occurrence of drugs in German sewage treatment plants and rivers1Dedicated to Professor Dr. Klaus Haberer on the occasion of his 70th birthday.1. Water Research 1998, 32, 3245-3260, https://doi.org/10.1016/S0043-1354(98)00099-2.

83. Altenburger, R.; Backhaus, T.; Boedeker, W.; Faust, M.; Scholze, M.; Grimme, L.H. Predictability of the toxicity of multiple chemical mixtures to Vibrio fischeri: mixtures composed of similarly acting chemicals. Environmental Toxicology and Chemistry: An International Journal 2000, 19, 2341-2347, https://doi.org/10.1002/etc.5620190926.

84. Pavithra, K.G.; Senthil Kumar, P.; Sundar Rajan, P.; Saravanan, A.; Naushad, M. Sources and impacts of pharmaceutical components in wastewater and its treatment process: A review. Korean Journal of Chemical Engineering 2017, 34, 2787-2805, https://doi.org/10.1007/s11814-017-0255-2.

85. Parihar, K.; Sankhla, M. S.; Kumar, R.; Singh, A. Assessment of Copper and Iron Concentration in Water of Yamuna River, Delhi, India. Letters in Applied NanoBioScience 2020, 10, 2251-2257. https://dx.doi.org/10.33263/LIANBS102.22512257. 
86. Gröning, J.; Held, C.; Garten, C.; Claußnitzer, U.; Kaschabek, S.R.; Schlömann, M. Transformation of diclofenac by the indigenous microflora of river sediments and identification of a major intermediate. Chemosphere 2007, 69, 509-516, https://doi.org/10.1016/j.chemosphere.2007.03.037.

87. Yadav, H.; Kumar, R.; Sankhla, M.S. Residues of Pesticides and Heavy Metals in Crops Resulting in Toxic Effects on Living Organism. Journal of Seybold Report ISSN NO, 1533 2020, 9211, https://doi.org/10.13140/RG.2.2.24806.65609.

88. Halling-Sørensen, B.; Nors Nielsen, S.; Lanzky, P.F.; Ingerslev, F.; Holten Lützhøft, H.C.; Jørgensen, S.E. Occurrence, fate and effects of pharmaceutical substances in the environment- A review. Chemosphere 1998, 36, 357-393, https://doi.org/10.1016/S0045-6535(97)00354-8.

89. Clara, M.; Kreuzinger, N.; Strenn, B.; Gans, O.; Kroiss, H. The solids retention time—a suitable design parameter to evaluate the capacity of wastewater treatment plants to remove micropollutants. Water Research 2005, 39, 97-106, https://doi.org/10.1016/j.watres.2004.08.036.

90. Singh, D.B.; Mandal, K. Environmental impact of pesticides belonging to newer chemistry. Integrated Pest Management 2013, 152-190.

91. Acosta-Sánchez, A.; Soto-Garita, C.; Masís-Mora, M.; Cambronero-Heinrichs, J.C.; Rodríguez-Rodríguez, C.E. Impaired pesticide removal and detoxification by biomixtures during the simulated pesticide application cycle of a tropical agricultural system. Ecotoxicology and Environmental Safety 2020, 195, https://doi.org/10.1016/j.ecoenv.2020.110460.

92. Fent, K. Effects of pharmaceuticals on aquatic organisms. In: Pharmaceuticals in the Environment. Springer, Berlin, Heidelberg. 2008, pp. 175-203, https://doi.org/10.1007/978-3-540-74664-5_12.

93. Grenni, P.; Patrolecco, L.; Ademollo, N.; Tolomei, A.; Barra Caracciolo, A. Degradation of Gemfibrozil and Naproxen in a river water ecosystem. Microchemical Journal 2013, 107, 158-164, https://doi.org/10.1016/j.microc.2012.06.008.

94. Pal, R.; Megharaj, M.; Kirkbride, K.P.; Naidu, R. Illicit drugs and the environment - A review. Science of The Total Environment 2013, 463-464, 1079-1092, https://doi.org/10.1016/j.scitotenv.2012.05.086.

95. Hartwig, C.; Muth-Köhne, E.; Düring, R.-A. Screening for eco-toxicological effects of antiepileptic drugs in biologically treated waste water originating from an epilepsy ward by Danio rerio embryos. Environmental Sciences Europe 2013, 25, https://doi.org/10.1186/2190-4715-25-29.

96. Berendonk, T.U.; Manaia, C.M.; Merlin, C.; Fatta-Kassinos, D.; Cytryn, E.; Walsh, F.; Bürgmann, H.; Sørum, H.; Norström, M.; Pons, M.-N.; Kreuzinger, N.; Huovinen, P.; Stefani, S.; Schwartz, T.; Kisand, V.; Baquero, F.; Martinez, J.L. Tackling antibiotic resistance: the environmental framework. Nature Reviews Microbiology 2015, 13, 310-317,https://doi.org/10.1038/nrmicro3439.

97. de Jesus Gaffney, V.; Almeida, C.M.; Rodrigues, A.; Ferreira, E.; Benoliel, M.J.; Cardoso, V.V. Occurrence of pharmaceuticals in a water supply system and related human health risk assessment. Water research $\mathbf{2 0 1 5}$, 72, 199-208, https://doi.org/10.1016/j.watres.2014.10.027.

98. Berendonk, T.U.; Manaia, C.M.; Merlin, C.; Fatta-Kassinos, D.; Cytryn, E.; Walsh, F.; Bürgmann, H.; Sørum, H.; Norström, M.; Pons, M.-N.; Kreuzinger, N.; Huovinen, P.; Stefani, S.; Schwartz, T.; Kisand, V.; Baquero, F.; Martinez, J.L. Tackling antibiotic resistance: the environmental framework. Nature Reviews Microbiology 2015, 13, 310-317,https://doi.org/10.1016/S0378-4274(03)00071-7.

99. Maggioni, S.; Balaguer, P.; Chiozzotto, C.; Benfenati, E. Screening of endocrine-disrupting phenols, herbicides, steroid estrogens, and estrogenicity in drinking water from the waterworks of 35 Italian cities and from PET-bottled mineral water. Environmental Science and Pollution Research 2013, 20, 1649-1660, https://doi.org/10.1007/s11356-012-1075-x.

100. Brody, J.G.; Aschengrau, A.; McKelvey, W.; Swartz, C.H.; Kennedy, T.; Rudel, R.A. Breast cancer risk and drinking water contaminated by wastewater: a case control study. Environmental Health 2006, 5, https://doi.org/10.1186/1476-069X-5-28.

101. Sankhla, M.S.; Kumar, R. Contaminant of Heavy Metals in Groundwater \& its Toxic Effects on Human Health \& Environment. Available at $\quad$ SSRN https://doi.org/10.19080/IJESNR.2019.18.555996.

102. Pouzol, T.; Lévi, Y.; Bertrand-Krajewski, J.-L. Modelling daily and hourly loads of pharmaceuticals in urban wastewater. International Journal of Hygiene and Environmental Health 2020, 229, https://doi.org/10.1016/j.ijheh.2020.113552.

103. Ramirez-Sanchez, I.M.; Apul, O.G.; Saleh, N.B. Photocatalytic activity of micron-scale brass on emerging pollutant degradation in water: mechanism elucidation and removal efficacy assessment. RSC Advances 2020, 10, 39931-39942, https://doi.org/10.1039/D0RA06153K.

104. Zarei, S.; Salimi, Y.; Repo, E.; Daglioglu, N.; Safaei, Z.; Güzel, E.; Asadi, A. A global systematic review and meta-analysis on illicit drug consumption rate through wastewater-based epidemiology. Environmental Science and Pollution Research 2020, 27, 36037-36051, https://doi.org/10.1007/s11356-020-09818-6.

105. Mechelke, J.; Rust, D.; Jaeger, A.; Hollender, J. Enantiomeric Fractionation during Biotransformation of Chiral Pharmaceuticals in Recirculating Water-Sediment Test Flumes. Environmental Science \& Technology 2020, 54, 7291-7301, https://doi.org/10.1021/acs.est.0c00767. 
106. Verbruggen, E.M.J.; Smit, C.E.; van Vlaardingen, P.L.A. Environmental quality standards for barium in surface water: Proposal for an update according to the methodology of the Water Framework Directive. 2020.

107. Darland, T.; Dowling, J.E. Behavioral screening for cocaine sensitivity in mutagenized zebrafish. PNAS 2001, 98, 11691-6, https://doi.org/10.1073/pnas.191380698.

108. Binelli, A.; Pedriali, A.; Riva, C.; Parolini, M. Illicit drugs as new environmental pollutants: Cyto-genotoxic effects of cocaine on the biological model Dreissena polymorpha. Chemosphere 2012, 86, 906-911, https://doi.org/10.1016/j.chemosphere.2011.10.056.

109. Gagné, F.; Blaise, C.; Fournier, M.; Hansen, P.D. Effects of selected pharmaceutical products on phagocytic activity in Elliptio complanata mussels. Comparative Biochemistry and Physiology Part C: Toxicology \& Pharmacology 2006, 143, 179-186, https://doi.org/10.1016/j.cbpc.2006.01.008.

110. Newby, N.C.; Mendonça, P.C.; Gamperl, K.; Stevens, E.D. Pharmacokinetics of morphine in fish: Winter flounder (Pseudopleuronectes americanus) and seawater-acclimated rainbow trout (Oncorhynchus mykiss). Comparative Biochemistry and Physiology Part C: Toxicology \& Pharmacology 2006, 143, 275-283, https://doi.org/10.1016/j.cbpc.2006.03.003.

111. Fontes, M.K.; Maranho, L.A.; Pereira, C.D.S. Review on the occurrence and biological effects of illicit drugs in aquatic ecosystems. Environmental Science and Pollution Research 2020, 27, 30998-31034, https://doi.org/10.1007/s11356-020-08375-2.

112. UNODC (United Nations Office on Drugs and Crime). World Drug Report, Viena, AT: United Nations 133, 2014.

113. UNODC (United Nations Office on Drugs and Crime). World Drug Report. United Nations publication, https://www.unodc.org/unodc/en/about-unodc/annual-report.html, Accessed 10 May 2019. Sales No. E.15.XI.6. 162p, 2014.

114. Parolini, M.; Binelli, A. Adverse effects induced by ecgonine methyl ester to the zebra mussel: A comparison with the benzoylecgonine. Environmental Pollution 2013, 182, 371-378, https://doi.org/10.1016/j.envpol.2013.07.038.

115. Parolini, M.; Binelli, A. Oxidative and genetic responses induced by $\Delta$-9-tetrahydrocannabinol ( $\Delta-9-\mathrm{THC})$ to Dreissena polymorpha. Science of the total environment 2014, 468-469, 68-76, https://doi.org/10.1016/j.scitotenv.2013.08.024.

116. Petrie, B.; Barden, R.; Kasprzyk-Hordern, B. A review on emerging contaminants in wastewaters and the environment: Current knowledge, understudied areas and recommendations for future monitoring. Water Research 2015, 72, 3-27,https://doi.org/10.1016/j.watres.2014.08.053.

117. Darland, T.; Dowling, J.E. Behavioral screening for cocaine sensitivity in mutagenized zebrafish. Proceedings of the National Academy of Sciences 2001, 98, 11691-11696, https://doi.org/10.1073/pnas.191380698.

118. Sloan, M.A. Illicit drug use/abuse and stroke. Handbook of clinical neurology 2008, 93, 823-840, https://doi.org/10.1016/S0072-9752(08)93041-4.

119. Ankley, G.T.; Brooks, B.W.; Huggett, D.B.; Sumpter, A.J.P. Repeating History: Pharmaceuticals in the Environment. Environmental Science \& Technology 2007, 41, 8211-8217, https://doi.org/10.1021/es072658j.

120. Zhou, S.N.; Oakes, K.D.; Servos, M.R.; Pawliszyn, J. Application of solid-phase microextraction for in vivo laboratory and field sampling of pharmaceuticals in fish. Environmental science \& technology 2008, 42, 6073-6079, https://doi.org/10.1021/es8001162.

121. Valcárcel, Y.; Martínez, F.; González-Alonso, S.; Segura, Y.; Catalá, M.; Molina, R.; Barceló, D. Drugs of abuse in surface and tap waters of the Tagus River basin: heterogeneous photo-Fenton process is effective in their degradation. Environment international 2012, 41, 35-43, https://doi.org/10.1016/j.envint.2011.12.006.

122. Verlicchi, P. Current Opinion in Environmental Science \& Health. 2018.

123. Nikolaou, A.; Meric, S.; Fatta, D. Occurrence patterns of pharmaceuticals in water and wastewater environments. Analytical and Bioanalytical Chemistry 2007, 387, 1225-1234, https://doi.org/10.1007/s00216-006-1035-8.

124. Włodarczyk-Makuła, M. Selected organic micro-pollutants in waters and soils. Publishing house of the Częstochowa University of Technology, 2013

125. Scheurer, M.; Ramil, M.; Metcalfe, C.D.; Groh, S.; Ternes, T.A. The challenge of analyzing beta-blocker drugs in sludge and wastewater. Anal Bioanal Chem 2010, 396, 845-856, https://doi.org/10.1007/s00216009-3225-7.

126. Verlicchi, P.; Al Aukidy, M.; Zambello, E. Occurrence of pharmaceutical compounds in urban wastewater: Removal, mass load and environmental risk after a secondary treatment-A review. Science of The Total Environment 2012, 429, 123-155, https://doi.org/10.1016/j.scitotenv.2012.04.028.

127. Hernando, M.D.; Agüera, A.; Fernández-Alba, A.R. LC-MS analysis and environmental risk of lipid regulators. Analytical and Bioanalytical Chemistry 2007, 387, 1269-1285, https://doi.org/10.1007/s00216006-0781-y. 
128. Monteiro, S.C.; Boxall, A.B. Occurrence and fate of human pharmaceuticals in the environment. In: Reviews of environmental contamination and toxicology. Springer, New York, NY. 2010; pp. 53-154, https://doi.org/10.1007/978-1-4419-1157-5_2.

129. Ziylan, A.; Ince, N.H. The occurrence and fate of anti-inflammatory and analgesic pharmaceuticals in sewage and fresh water: Treatability by conventional and non-conventional processes. Journal of Hazardous Materials 2011, 187, 24-36, https://doi.org/10.1016/j.jhazmat.2011.01.057.

130. Salgado, R.; Marques, R.; Noronha, J.P.; Carvalho, G.; Oehmen, A.; Reis, M.A.M. Assessing the removal of pharmaceuticals and personal care products in a full-scale activated sludge plant. Environmental Science and Pollution Research 2012, 19, 1818-1827, https://doi.org/10.1007/s11356-011-0693-z.

131. Radjenović, J.; Matošić, M.; Mijatović, I.; Petrović, M.; Barceló, D. Membrane bioreactor (MBR) as an advanced wastewater treatment technology. In: Emerging Contaminants from Industrial and Municipal Waste. Springer, Berlin, Heidelberg. 2007; pp. 37-101, https://doi.org/10.1007/698_5_093.

132. Klavarioti, M.; Mantzavinos, D.; Kassinos, D. Removal of residual pharmaceuticals from aqueous systems by advanced oxidation processes. Environment International 2009, 35, 402-417, https://doi.org/10.1016/j.envint.2008.07.009.

133. Tambosi, J.L.; de Sena, R.F.; Favier, M.; Gebhardt, W.; José, H.J.; Schröder, H.F.; Moreira, R.d.F.P.M. Removal of pharmaceutical compounds in membrane bioreactors (MBR) applying submerged membranes. Desalination 2010, 261, 148-156, https://doi.org/10.1016/j.desal.2010.05.014.

134. Calza, P.; Medana, C.; Padovano, E.; Giancotti, V.; Minero, C. Fate of selected pharmaceuticals in river waters. Environmental Science and Pollution Research 2013, 20, 2262-2270, https://doi.org/10.1007/s11356-012-1097-4.

135. Nentwig, G. Another example of effects of pharmaceuticals on aquatic invertebrates: fluoxetine and ciprofloxacin. In: Pharmaceuticals in the Environment. Springer, Berlin, Heidelberg. 2008; pp. 205-222, https://doi.org/10.1007/978-3-540-74664-5_13.

136. Bartelt-Hunt, S.L.; Snow, D.D.; Damon, T.; Shockley, J.; Hoagland, K. The occurrence of illicit and therapeutic pharmaceuticals in wastewater effluent and surface waters in Nebraska. Environmental Pollution 2009, 157, 786-791,https://doi.org/10.1016/j.envpol.2008.11.025.

137. Stadler, L.B.; Ernstoff, A.S.; Aga, D.S.; Love, N.G. Micropollutant Fate in Wastewater Treatment: Redefining "Removal". Environmental Science \& Technology 2012, 46, 10485-10486, https://doi.org/10.1021/es303478w.

138. Kasprzyk-Hordern, B.; Baker, D.R. Enantiomeric Profiling of Chiral Drugs in Wastewater and Receiving Waters. Environmental Science \& Technology 2012, 46, 1681-1691, https://doi.org/10.1021/es203113y.

139. Bijlsma, L.; Emke, E.; Hernández, F.; de Voogt, P. Investigation of drugs of abuse and relevant metabolites in Dutch sewage water by liquid chromatography coupled to high resolution mass spectrometry. Chemosphere 2012, 89, 1399-1406, https://doi.org/10.1016/j.chemosphere.2012.05.110.

140. Postigo, C.; Lopez de Alda, M.J.; Barceló, D. Fully Automated Determination in the Low Nanogram per Liter Level of Different Classes of Drugs of Abuse in Sewage Water by On-Line Solid-Phase ExtractionLiquid Chromatography-Electrospray-Tandem Mass Spectrometry. Analytical Chemistry 2008, 80, 31233134, https://doi.org/10.1021/ac702060j.

141. Petrovic, M.; de Alda, M.J.L.; Diaz-Cruz, S.; Postigo, C.; Radjenovic, J.; Gros, M.; Barcelo, D. Fate and removal of pharmaceuticals and illicit drugs in conventional and membrane bioreactor wastewater treatment plants and by riverbank filtration. Philosophical Transactions of the Royal Society A: Mathematical, Physical and Engineering Sciences 2009, 367, 3979-4003, https://doi.org/10.1098/rsta.2009.0105.

142. Jekel, M.; Dott, W.; Bergmann, A.; Dünnbier, U.; Gnirß, R.; Haist-Gulde, B.; Hamscher, G.; Letzel, M.; Licha, T.; Lyko, S.; Miehe, U.; Sacher, F.; Scheurer, M.; Schmidt, C.K.; Reemtsma, T.; Ruhl, A.S. Selection of organic process and source indicator substances for the anthropogenically influenced water cycle. Chemosphere 2015, 125, 155-167, https://doi.org/10.1016/j.chemosphere.2014.12.025. 